\title{
Role of gastrointestinal hormones in feeding behavior and obesity treatment
}

\author{
Timothy Sean Kairupan ${ }^{1,2} \cdot$ Haruka Amitani ${ }^{1} \cdot$ Kai-Chun Cheng ${ }^{1} \cdot$ \\ Joshua Runtuwene $^{1,2} \cdot$ Akihiro Asakawa ${ }^{1}$ - Akio Inui ${ }^{1}$
}

Received: 19 August 2015/Accepted: 20 August 2015/Published online: 7 September 2015

(C) Springer Japan 2015

\begin{abstract}
Food intake regulation is generally evaluated by many aspects consisting of complex mechanisms, including homeostatic regulatory mechanism, which is based on negative feedback, and hedonic regulatory mechanism, which is driven by a reward system. One important aspect of food intake regulation is the peripheral hormones that are secreted from the gastrointestinal tract. These hormones are secreted from enteroendocrine cells as feedback to nutrient and energy intake, and will communicate with the brain directly or via the vagus nerve. Gastrointestinal hormones are very crucial in maintaining a steady body weight, despite variations in nutrient intake and energy expenditure. In this review, we provide an overview of the regulation of feeding behavior by gut hormones, and its role in obesity treatments.
\end{abstract}

Keywords Gastrointestinal hormone - Feeding behavior . Obesity $\cdot$ Clinical application

\section{Introduction}

Currently, obesity and its comorbidities have become a critical problem throughout the world. Obesity is defined as an abnormal and excessive fat accumulation caused by an imbalance of energy intake and caloric expenditure that

Akio Inui

inui@m.kufm.kagoshima-u.ac.jp

1 Department of Psychosomatic Internal Medicine, Kagoshima University Graduate School of Medical and Dental Sciences, 8-35-1 Sakuragaoka, Kagoshima 890-8544, Japan

2 Faculty of Medicine, Sam Ratulangi University, Manado, Indonesia may impair the health. Overweight is categorized by a body mass index (BMI) over $25 \mathrm{~kg} / \mathrm{m}^{2}$, and obese is categorized by a BMI exceeding $30 \mathrm{~kg} / \mathrm{m}^{2}$. However, in some Asian countries, the risk of type 2 diabetes and cardiovascular disease is substantial at BMIs lower than the existing World Health Organization (WHO) cutoff point for overweight. Thus, in different Asian populations, the cutoff point for observed risk varies from 22 to $25 \mathrm{~kg} / \mathrm{m}^{2}$, while for high risk, it varies from 26 to $31 \mathrm{~kg} / \mathrm{m}^{2}$. WHO has declared that obesity is one of the 10 at-risk conditions around the world and one of the 5 at-risk conditions in developing countries. In 2014, more than 1.9 billion adults are overweight and 600 million are obese.

In general, both overweight and obesity are associated with a high prevalence of comorbidities, including high blood pressure, metabolic syndrome, type 2 diabetes mellitus (T2DM), cardiovascular disease, and many others. A study suggested that a $1-\mathrm{kg}$ weight gain increases the risk of diabetes by $4.5-9 \%$ and cardiovascular disease by $3.1 \%$. [1]. Relating to obesity, the gastrointestinal tract is an important source of food intake. Gut hormones have a major role in controlling and regulating food intake. With the growing obesity crisis, gut hormones have become a hot topic of research among the scientists. Therefore, we are interested in the role of gut hormones in food intake regulation and in the treatment of obesity.

\section{Overview of neuroendocrine regulation in food intake}

The food that we eat is broken down into small parts, which contains many nutrients. These nutrients may activate the G-protein-coupled receptors (GPCR) in the luminal side of enteroendocrine cells [2]. The 
gastrointestinal tract contains many types of enteroendocrine cells. Combined together, it becomes the largest endocrine organ in the body. When activated, it releases several hormones that have an impact on many physiological processes, including the food intake [3]. These hormones, including gut hormones, will pass median eminence and signal short-term nutrient availability to the hypothalamic arcuate nucleus (ARC) [4, 5]. Other circulating peptides, such as leptin released from the adipose tissue as well as insulin, are responsible for signaling the long-term energy stores and adiposity [6].

The ARC in the hypothalamus is known to regulate food intake and energy expenditure [7, 8]. It contains two populations of neurons that show an opposite effect to one another. The medial parts act as an orexigenic neurons that express neuropeptide Y (NPY) and agouti-related protein (AgRP) [9-11]. In the lateral side of ARC contains anorexigenic neurons that express alpha-melanocyte-stimulating hormone $(\alpha-\mathrm{MSH})$ derived from pro-opiomelanocortin (POMC) and cocaine and amphetamineregulated transcript (CART) [12].

Moreover, other peripheral signals perform actions through the afferent neuron and brainstem that will indirectly influence the hypothalamus. The mechanoreceptors and/or chemoreceptors also contribute to control of the appetite. Both receptors activate the vagal afferent, and the neural signals converge in the nucleus of tractus solitarius (NTS) of the brainstem. Then these signals are transmitted to hypothalamus [13]. Eventually, several gut hormones are also known to act via the ascending vagal pathway and brainstem [14].

Therefore, the orexigenic and anorexigenic neurons in the hypothalamus are regulated by many neural and hormonal signals (Fig. 1). These neurons will then project to other neurons in the extra-hypothalamic and intra-hypothalamic regions, such as the hypothalamic paraventricular nucleus (PVN), and lateral hypothalamus (LH) and perifornical area (PFA), where some of the important efferent pathways regulating hunger, satiety, and energy expenditure arise [15].

\section{Gut hormones and food intake regulation}

\section{Ghrelin}

Ghrelin, a peptide consisted 28 amino acids with n-octanoylated Ser3, was reported in 1999 as an endogenous ligand for the 'orphan' growth hormone secretogogue (GHS) [16, 17]. Ghrelin is predominantly found in the stomach, and was the first hormone to be identified for stimulating food intake [18]. It acts mainly as an orexigenic signal sending information about peripheral caloric intake to the brain center for energy homeostasis.



Fig. 1 Neuroendocrine overview of food intake. Nutrients from food digestion will activate G-protein-coupled receptors on the luminal side of enteroendocrine cells. This leads to the release of gastrointestinal hormones, which will perform their action through three sites: the hypothalamus, brainstem, and vagus nerve. These hormones will signal short-term nutrient availability to the hypothalamic arcuate nucleus (ARC). The ARC in the hypothalamus is known to regulate food intake and energy expenditure. It contains two populations of neurons that show an opposite effect to one another: the orexigenic NPY/AgRP neurons and the anorexigenic POMC/CART neurons. Both neurons will project to higher brain centers that control the hedonic aspects of food ingestion. $A R C$ arcuate nucleus; $A g R P$ agouti related peptide; $C A R T$ cocaine and amphetamine-regulated transcript; $C C K$ (Cholecystokinin; GLP-1 glucagon like peptide-1; NPY neuropeptide Y; $O X M$ oxyntomodulin; $P O M C$ propiomelanocortin; $P P$ pancreatic peptide; $P Y Y$ peptide $Y Y$ 
Orexigenic NPY and AgRP-expressing neurons are involved in this mechanism because they express the ghrelin receptor $[19,20]$, which may respond to ghrelin by increasing the firing rate. Intracerebroventricular (ICV) administration of ghrelin increases body weight by increasing the cumulative food intake and energy expenditure reduction [21-24]. Ghrelin secretion is mainly regulated by feeding. In human studies, plasma ghrelin levels increase during fasting, and surge nearly twofold immediately preprandial, and drop within $1 \mathrm{~h}$ after food intake [25]. Prandial changes in the plasma ghrelin levels occur in association with the changes in hunger score, even when external cues related to time of day have been removed from environment [26]. These findings suggest that plasma ghrelin plays a role in short-term energy balance [27]. In addition to the regulation of appetite and energy balance, ghrelin also contributes to long-term body weight regulation. Ghrelin levels circulate in relation to the energy stores and manifest the compensatory changes in response to body weight alteration, increasing weight loss and vice versa [28].

Besides its direct effect on the brain, ghrelin is also suggested to act through the vagal neurons [29]. The existence of ghrelin receptors on vagal afferent neurons in the rat's nodose ganglion indicates that ghrelin signals from the stomach are transmitted to the hypothalamus through vagal neurons [30]. In animal models, vagotomy abolished the orexigenic effect of ghrelin [31]. The food intake stimulatory effect of ghrelin also disappeared in humans after vagotomy [32].

\section{Cholecystokinin}

Cholecystokinin (CCK) is a gut satiating peptide that is produced by I cells in small intestine [33]. Basically, CCK is released post-prandially in response to saturated fats, long chain fatty acids, amino acids, and small peptides, and is reduced gradually upon fasting [34-36]. Peripheral administration of CCK before a meal may decrease the meal size in a dose-dependent manner, both in experimental animals [37, 38] and human subjects [39, 40]. CCK acts as a short-acting satiation signal, but not for long-term body weight regulation. It has a very short lifespan; according to a previous report, the peptide was not detectable when it was injected for more than $30 \mathrm{~min}$ before the meal [41].

There are several forms of CCK, ranging from 8 to 83 chain amino acids. The major circulating forms are CCK-8, CCK-22, CCK-33, and CCK-58, all having the same attribute, a C-terminal heptapeptide amide sequence for binding [42-44]. Although they have the same attribute, not all forms of CCK show equal bioactivity; for example, both CCK-8 and CCK-58 can reduce meal size after administration, but only CCK-58 increases the intermeal interval time, while CCK- 8 reduces this interval, as shown in previous studies [45, 46].

CCK performs its action through cholecystokinin-1 (CCK1) receptors and/or cholecystokinin-2 (CCK2) receptors [47]. CCK1 receptors are responsible for mediating the anorexigenic effect of CCK, mainly through vagal afferent fibers [48, 49], and this receptor is also located in brain $[50,51]$. Subdiaphramatic vagotomy and selective vagal deafferentation cause a decrease in the anorexigenic effects of peripheral CCK [52-54]. Furthermore, CCK1 receptors are also located in the hindbrain and hypothalamus, and microinjection of CCK into the hypothalamic nuclei may decrease food intake [55]. Additionally, lesions in the hindbrain Area Postrema (AP) proved to weaken the satiation effect of CCK [56]. These data indicate that to perform its action, CCK might communicate indirectly through the vagal nerve or directly to the brain.

\section{Peptide Tyrosine Tyrosine}

Peptide tyrosine tyrosine (PYY) is a 36-amino acid peptide with tyrosine $(\mathrm{Y})$ residues at the $\mathrm{N}$ and $\mathrm{C}$ terminals. It was isolated from porcine intestine in 1980 [57], and shares similiar structure with NPY and PP, consisting of an $\alpha$ helix and a polyproline helix connected by a $\beta$ turn, and together classified in the polypeptide-fold (PP-fold) family [58].

PYY is released from L-cells in the distal ileum and is increased along the intestine, reaching the highest levels in the colon and rectum. It is secreted following a meal, gradually rises, reaches the peak level within 1-2 h, and will remain elevated for $6 \mathrm{~h}[59,60]$. Meal composition has high influence on the release of PYY, with protein being greater then lipids and carbohydrates [61]. There are two main types of PYY, PYY ${ }_{1-36}$ and $\mathrm{PYY}_{3-36}, \mathrm{PYY}_{1-36}$ is proteolyzed by dipeptidyl-peptidase 4 (DPP4) to produce PYY $_{3-36}$ as the bioactive form $[62,63]$. PYY performs its action through the $\mathrm{Y}$ receptor family (Y1, Y2, Y4, Y5, and Y6), where $P Y Y_{3-36}$ has a high affinity toward $\mathrm{Y} 2$ receptors and low affinity to $\mathrm{Y} 1$ and $\mathrm{Y} 5$ receptors [64, 65].

Peripheral administration of $\mathrm{PYY}_{3-36}$ in rodents decreased appetite and food intake [66-68], and also reduced body weights in other experimental animals [69, 70]. In human, intravenous infusion of $\mathrm{PYY}_{3-36}$ also showed the same results, indicating the role of PYY as an anorexigenic peptide [71]. This anorectic effect is mainly mediated through Y2 receptors in the hypothalamic ARC, and will inhibit the NPY/AgRP neurons, which activates the anorectic melanocortin-producing cells [66]. The anorexigenic effect of $\mathrm{PYY}_{3-36}$ disappears in $\mathrm{Y} 2$ receptordeficient animals [66, 72, 73]. Surprisingly, direct administration of PYY into the brain results in an increase 
of food intake. This result might be due to the differential access to $\mathrm{Y}$ receptors, in which the orexigenic effect is predicted come from the interaction between PYY with $\mathrm{Y} 1$ and Y5 receptors in the brain [74, 75]. Furthermore, the vagal-brainstem-mediated pathway may also be involved in the action of circulating $\mathrm{PYY}_{3-36}$. Y2 receptors are located in vagal-afferent terminals. Several studies have confirmed that abdominal vagotomy or transection of hindbrain-hypothalamic pathways in rodent abolishes the anorectic effects and the ARC neuronal activation of PYY $[76,77]$. In summary, PYY acts as a satiety signal that may reduce the food intake in rodents as well as in humans, and performs its action directly through Y2 receptors in the hypothalamic ARC and/or through the vagal afferent.

\section{Glucagon-like peptide-1}

Glucagon-like peptide-1 (GLP-1) is a gut peptide derived from preproglucagon. It is produced in the body, mainly the intestinal L-cells, in response of glucose ingestion [78]. A study showed that high protein food intake increases the concentration of GLP-1 [79]. Cleavage of the preproglucagon resulted into two main bioactive forms of GLP-1, GLP- $1_{7-36}$ and the GLP-1 ${ }_{7-37}$ [80]. Both forms have a short biological half-life, because both of them are rapidly degraded during circulation by dipeptidil peptidase 4 (DPP4) [81].

Acute peripheral and central administration of GLP-1 reduced food intake in animals [82-84], and chronic administration proved to reduce weight gain [85]. In human subjects, intravenous injection of GLP-1 decreases the food intake in a dose-dependent manner [86-89], and it also activates the ileal break [90], a feedback in which ingested food activates distal-intestinal signals to inhibit the proximal gastrointestinal motility and gastric emptying. Beside of its anorexigenic property, GLP-1 also has an important role in glucose homeostasis. It acts as an incretin to induce glucose-dependent insulin release and enhance pancreas $\beta$ cell growth in addition to reduced secretion of glucagon [91]. GLP-1 actions are mainly mediated through the GLP1 receptors (GLP1R), located in pancreas, brainstem, hypothalamus, and vagal nerves. Peripheral injection of GLP-1 has been shown to activate neurons in the brainstem of rats [92]. The anorectic property of GLP-1 is diminished in vagotomized rodents [76]. Furthermore, using magnetic resonance imaging (MRI), scientists have confirmed that peripheral administration of GLP-1 increased the signal intensity in the brainstem's AP, and it also altered signal intensity in the hypothalamic PVN and ventromedial nucleus (VMN) [93]. Therefore, GLP-1 achieves its action both centrally through the hypothalamus and through the vagal-brainstem signalling pathway.

\section{Oxyntomodulin}

Oxyntomodulin (OXM) is a gut peptide similar to GLP-1 and is derived from the same precursor, preproglucagon. It is cosecreted with GLP-1 from enteroendocrine L-cells postprandially in response to caloric intake [94]. OXM administration in rodents has been shown to decrease food intake and body weight $[95,96]$, and also to increase energy expenditure [97]. In normal weight humans, intravenous administration of OXM has been shown to reduce food intake [98], while in overweight and obese volunteers, administration of OXM increases energy expenditure and reduces energy intake [99, 100].

OXM has an affinity for both GLP-1 receptors and glucagon receptors. However, it is believed that the anorectic effect of OXM is mediated mainly through GLP1 receptors [101], although recent data indicate that glucagon receptors are also involved in OXM action [102]. OXM has lower affinity to GLP-1 receptors than GLP-1, but it still has similar potency to GLP-1 in reducing food intake [95]. GLP-1 receptor knockout mice and administration of the GLP-1 receptor antagonist exendin 9-39 abolished the anorectic effect of OXM [101]. However, exendin 9-39 did not affect the anorectic effect of GLP-1 [96]. Similar to this, one study using manganese-enhanced magnetic resonance imaging (MEMRI) showed that intraperitoneally injected OXM reduces the neuronal activity in the ARC, PVN, and supraoptic nucleus (SON) [103]. Therefore, despite OXM and GLP-1 sharing simillar attributes, these two hormones might act through different hypothalamic pathways.

\section{Pancreatic polypeptide and amylin}

Pancreatic polypeptide (PP) is a 36-amino acid peptide that belongs to the "PP-fold" family of peptides. It is released from the pancreas postprandially in response to caloric load, and is controlled mainly by vagal cholinergic mechanism [104]. Many studies have shown that PP decreases food intake with a delay of gastric emptying after peripheral administration in humans and rodents [105-107]. PP can interact with all subtypes of the $\mathrm{Y}$ receptor family, while it has the highest affinity toward Y4 receptors, particularly in the VMN, PVN, AP, and ARC [107-109].

Amylin or islet amyloid polypeptide (IAPP) is a 37-residue peptide that is cosecreted with insulin from pancreatic $\beta$ cells in response to food intake [110]. Amylin is known to slow down the gastric emptying and to inhibit gastric and glucagon secretion [111]. Peripheral and central administration of amylin decreased food intake $[112,113]$. In humans, peripheral administration of amylin analogue pramlintide enhanced satiety and reduced food intake, 


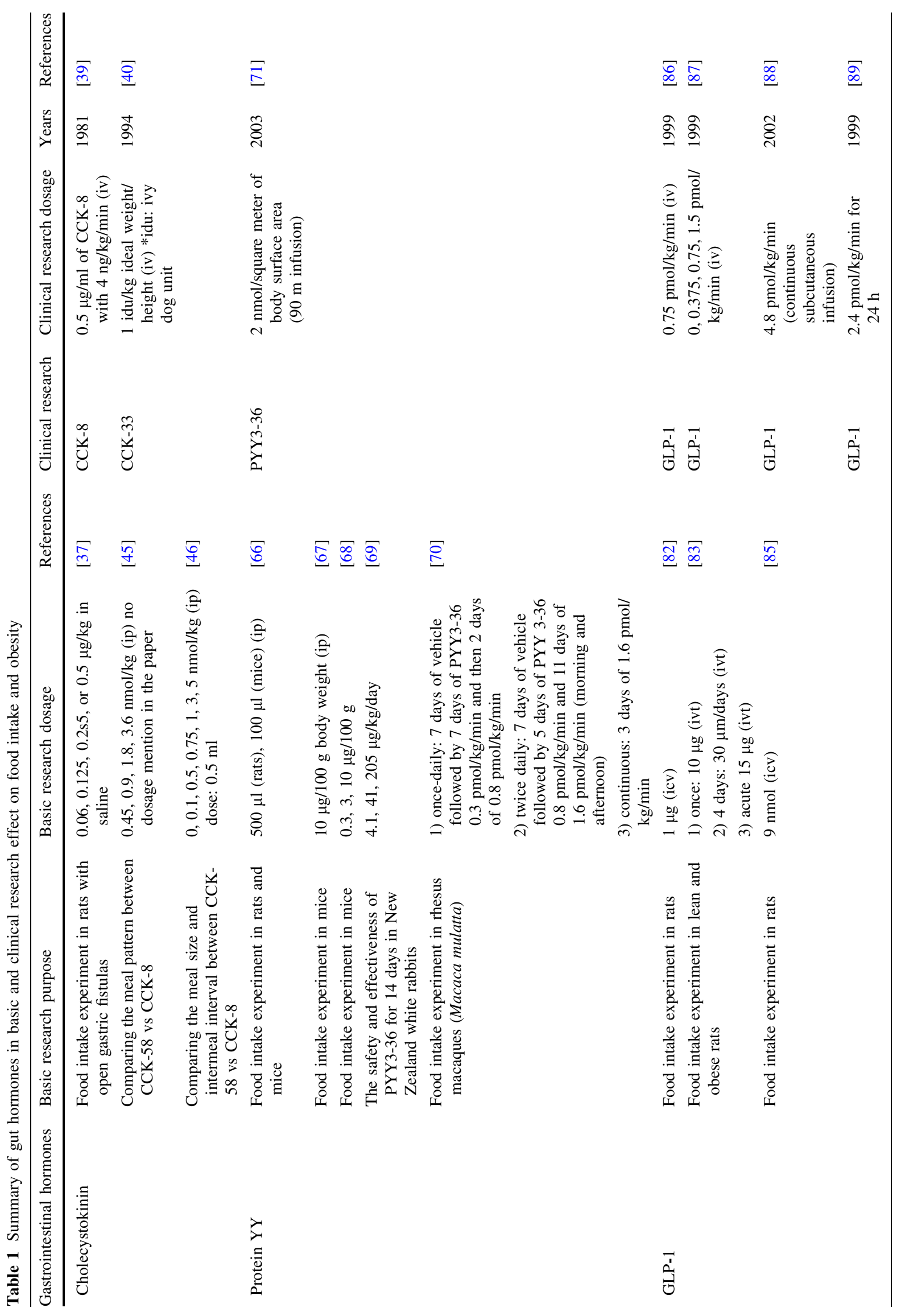




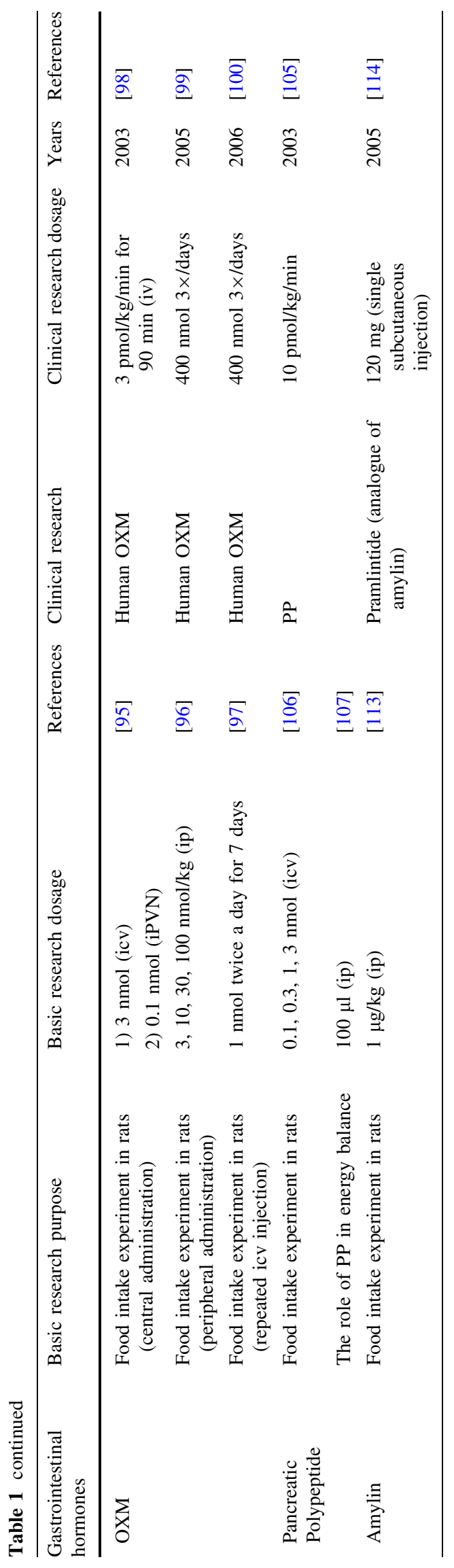

indicating the role of Amylin as an anorexigenic peptide [114]. Studies have shown that brain AP is the primary target of amylin for inducing the satiety action $[115,116]$.

\section{Gut hormones and obesity treatment}

Currently, three main steps are widely applied in obesity treatment: lifestyle modification, pharmacotherapy, and bariatric surgery [117]. Lifestyle modification focuses on increasing physical activity while having a healthier diet and lower calorie meals, and is usually used in obesity intervention. If the lifestyle intervention has failed and the patients meet the requirements for anti-obesity medication, then the use of anti-obesity drugs should be considered. The requirements to use pharmacotherapy in treating obesity, according to the Food and Drug Administration (FDA), are patients with a body mass index (BMI) $30-27 \mathrm{~kg} / \mathrm{m}^{2}$ who have associated high-risk comorbid conditions [118]. In clinics, the use of prescriptions for anti-obesity is $<3 \%$. Concerns regarding safety and adverse effects of anti-obesity drugs are the main reasonsfor this low prescription rate [119]. Several anti-obesity drugs have been withdrawn from the market due to adverse effects, such as: fenfluramin and dexfenfluramine in 1997, sibutramine in 2010 by the US Food and Drug Administration (FDA), and rimonabant in 2009 by the European Medicines Agency (EMA) [120]. The third option is bariatric surgery, usually targeted to severely obese patients (BMI $\geq 40$ or $\geq 35 \mathrm{~kg} / \mathrm{m}^{2}$ with comorbidity). Until now, bariatric surgery has mostly been applied in obesity treatment that has shown long-term, sustained weight loss and improving metabolic comorbidities [121]. Unfortunately, the expensive cost and the complications make it impractical to treat the growing population of obese worldwide [122].

Interestingly, some studies have shown that the clinical benefits of bariatric surgery in achieving weight loss and metabolic comorbidity improvement are related to alterations in gut hormone production [123, 124]. Ghrelin level after bariatric surgery showed mixed results. Several studies showed a decrease in ghrelin level after sleeve gastrectomy (SG) [125-127], and a decrease and/or no change after the duodenojejunal bypass (DJB) and biliopancreatic diversion (BPD) $[125,128]$, while others reported an increase and/or no change after the adjustable gastric band (AGB) [129-133]. These different results may be due to the variability in the time at which blood sample was taken, or by the variation in bariatric surgery. In 2006, postprandial circulating levels of PYY and GLP-1 were increased after the Roux-en-Y gastric bypass (RYGB) in humans $[134,135]$. Another study showed similar results in 34 patients after RYGB surgery, and the effect was 
sustained for 2 years [136]. CCK production has also been altered after bariatric surgery; patients with jujenoileal bypass showed an increase in CCK-containing cells [137] and CCK levels [138, 139]. All together, this shows that gut hormones have an important role in tackling the obesity crisis.

Gut hormone-based therapy has an advantage in the development of anti-obesity drugs. Endogenous gut hormones physiologically regulate food intake; thus, hormonebased therapy will have fewer side effects than chemical drugs. Many studies have been done in the past to investigate the effect of gut hormone administration in obese subjects (Table 1), and resulted in promising outcomes [39, 40, 86-90, 114]. Furthermore, an additive effect could be achieved with a combined administration of gut hormones; for example, a combination of PYY3-36 and GLP-1 administration showed an additive anorectic effect in both mice and human [140]. This opens the possibility of a combination therapy of gut hormones in treating obesity.

Gut hormone-based therapy might become useful in treating obesity in the future, but it still has several drawbacks. The first one is the short half-life of gut peptides. Long-acting analogues of several gut hormones have been developed to overcome this problem; the exenatide (exendin-4), for example, is a GLP-1 receptor agonist that is resistant toward DPP4, resulting in longer action in vivo than GLP-1 [141-143]. Some are still at the clinical trial phase, such as Y242 (a PYY analogue) [ClinicalTrial.gov Identifier: NCT01515319], PP1420 (a PP analogue) [ClinicalTrial.gov Identifier: NCT02221765], or the Pfizer's OAP-189 (an OXM analogue) [ClinicalTrial.gov Identifier: NCT00970593], and we are awaiting trial results for all.

The other drawback is the rapid degradation of gut peptides in the upper digestive system, resulting in limited bioactivity through oral administration of gut hormones. Recently, orally administration of gut hormones has been achieved using the sodium N-[8-(2-hydroxybenzoyl) amino] caprylate (SNAC) delivery technique, such as orally administered GLP-1 and PYY3-36 in human using the SNAC delivery technique to result in an additive anorectic effect [144]. This initial result suggests that oral administration of gut hormones could be applied in the near future. A new field in anti-obesity research is the study of nutrient sensing receptors. Studies have shown that targeting nutrient sensing receptors, such as the sweet taste receptor on the primary enteroendocrine L-cell cultures, causes the release of gut hormones [145, 146]. Oral administration of nutrient sensing agonists would be an effective way to treat obese patients. However, due to a lack of in vivo data, the physiological relevance of this application is still unclear and further research is required.

In summary, gastrointestinal hormones play an important role in energy homeostasis and food intake by affecting the brain areas that are associated with the regulation of eating behavior and appetite; acting either directly from the blood stream or via the vagus nerve. Modifying and commandeering gut hormones and/or their signaling pathways provides a promising target for antiobesity treatment in the future.

\section{Compliance with ethical standards}

Conflict of interest Akio Inui received a research grant from Vana $\mathrm{H}$. The other authors have no conflict of interest to declare.

\section{References}

1. Mokdad AH, Ford ES, Bowman BA, et al. Diabetes trends in the US: 1990-1998. Diabetes Care. 2000;23:1278-83.

2. Sam AH, Troke RC, Tan TM, Bewick GA. The role of the gut/ brain axis in modulating food intake. Neuropharmacology. 2012;63:46-56.

3. Ahlman $\mathrm{H}$, Nilsson $\mathrm{O}$. The gut as the largest endocrine organ in the body. Ann Oncol. 2001;12(Suppl 2):S63-8.

4. Peruzzo B, Pastor FE, Blázquez JL, et al. A second look at the barriers of the medial basal hypothalamus. Exp Brain Res. 2000;132:10-26.

5. Schaeffer M, Hodson DJ, Mollard P. The blood-brain barrier as a regulator of the gut-brain axis. Front Horm Res. 2014;42:29-49.

6. Porte D, Baskin DG, Schwartz MW. Leptin and insulin action in the central nervous system. Nutr Rev. 2002;60:S20-9.

7. Simpson KA, Martin NM, Bloom SR. Hypothalamic regulation of food intake and clinical therapeutic applications. Arq Bras Endocrinol Metabol. 2009;53:120-8.

8. Sainsbury A, Zhang L. Role of the arcuate nucleus of the hypothalamus in regulation of body weight during energy deficit. Mol Cell Endocrinol. 2010;316:109-19.

9. Bewick GA, Dhillo WS, Darch SJ, et al. Hypothalamic cocaineand amphetamine-regulated transcript (CART) and agouti-related protein (AgRP) neurons coexpress the NOP1 receptor and nociceptin alters CART and AgRP release. Endocrinology. 2005;146:3526-34.

10. Broberger C, Johansen J, Johansson C, et al. The neuropeptide Y/agouti gene-related protein (AGRP) brain circuitry in normal, anorectic, and monosodium glutamate-treated mice. Proc Natl Acad Sci USA. 1998;95:15043-8.

11. Hahn TM, Breininger JF, Baskin DG, Schwartz MW. Coexpression of Agrp and NPY in fasting-activated hypothalamic neurons. Nat Neurosci. 1998;1:271-2.

12. Elias CF, Lee C, Kelly J, et al. Leptin activates hypothalamic CART neurons projecting to the spinal cord. Neuron. 1998;21:1375-85.

13. Schwartz MW, Woods SC, Jr DP, et al. Central nervous system control of food intake. Nature 2000;404SChwa:661-671.

14. Jobst EE, Enriori PJ, Cowley MA. The electrophysiology of feeding circuits. Trends Endocrinol Metab. 2004;15:488-99.

15. Valassi E, Scacchi M, Cavagnini F. Neuroendocrine control of food intake. Nutr Metab Cardiovasc Dis. 2008;18:158-68.

16. Kojima M, Hosoda H, Date Y, et al. Ghrelin is a growth-hormone-releasing acylated peptide from stomach. Nature. 1999;402:656-60.

17. Hosoda H, Kojima M, Mizushima T, et al. Structural divergence of human ghrelin: identification of multiple ghrelin-derived molecules produced by post-translational processing. J Biol Chem. 2003;278:64-70. 
18. Date Y, Kojima M, Hosoda H, et al. Ghrelin, a novel growth hormone-releasing acylated peptide, is synthesized in a distinct endocrine cell type in the gastrointestinal tracts of rats and humans. Endocrinology. 2000;141:4255-61.

19. Guan X, Yu H, Palyha O, et al. Distribution of mRNA encoding the growth hormone secretagogue receptor in brain and peripheral tissues. Mol Brain Res. 1997;48:23-9.

20. Willesen MG, Kristensen P, Rømer J. Co-localization of growth hormone secretagogue receptor and NPY mRNA in the arcuate nucleus of the rat. Neuroendocrinology. 1999;70:306-16.

21. Kamegai J, Tamura H, Shimizu T, et al. Chronic central infusion of ghrelin increases hypothalamic neuropeptide $\mathrm{Y}$ and agoutirelated protein mRNA Levels and body weight in rats. Diabetes. 2001;50:2438-43.

22. Nakazato M, Murakami N, Date Y, et al. A role for ghrelin in the central regulation of feeding. Nature. 2001;409:194-8.

23. Tschöp M, Smiley DL, Heiman ML. Ghrelin induces adiposity in rodents. Nature. 2000;407:908-13.

24. Wren AM, Small CJ, Abbott CR, et al. Ghrelin causes hyperphagia and obesity in rats. Diabetes. 2001;50:2540-7.

25. Cummings DE, Weigle DS, Frayo RS, et al. Plasma ghrelin levels after diet-induced weight loss or gastric bypass surgery. N Engl J Med. 2002;346:1623-30.

26. Cummings DE, Frayo RS, Marmonier C, et al. Plasma ghrelin levels and hunger scores in humans initiating meals voluntarily without time- and food-related cues. Am J Physiol Endocrinol Metab. 2004;287:E297-304.

27. Pusztai P, Sarman B, Ruzicska E, et al. Ghrelin: a new peptide regulating the neurohormonal system, energy homeostasis and glucose metabolism. Diabetes Metab Res Rev. 2008;24:343-52.

28. Cummings DE. Ghrelin and the short- and long-term regulation of appetite and body weight. Physiol Behav. 2006;89:71-84.

29. Cheng K-C, Li Y-L, Asakawa A, Inui A. The role of ghrelin in energy homeostasis and its potential clinical relevance (review). Int J Mol Med. 2010;26:771-8.

30. Date Y, Murakami N, Toshinai K, et al. The role of the gastric afferent vagal nerve in Ghrelin-induced feeding and growth hormone secretion in rats. Gastroenterology. 2002;123:1120-8.

31. Williams DL, Grill HJ, Cummings DE, Kaplan JM. Vagotomy dissociates short- and long-term controls of circulating ghrelin. Endocrinology. 2003;144:5184-7.

32. Le Roux CW, Neary NM, Halsey TJ, et al. Ghrelin does not stimulate food intake in patients with surgical procedures involving vagotomy. J Clin Endocrinol Metab. 2005;90:4521-4.

33. Roth KA, Kim S, Gordon JI. Immunocytochemical studies suggest two pathways for enteroendocrine cell differentiation in the colon. Am J Physiol Gastrointest Liver Physiol. 1992;263:G174-80.

34. Lieverse RJ, Jansen JB, Masclee AA, et al. Effect of a low dose of intraduodenal fat on satiety in humans: studies using the type A cholecystokinin receptor antagonist loxiglumide. Gut. 1994;35:501-5.

35. Liddle RA, Goldfine ID, Rosen MS, et al. Cholecystokinin bioactivity in human plasma. Molecular forms, responses to feeding, and relationship to gallbladder contraction. J Clin Invest. 1985; 75:1144-52.

36. Crespo CS, Cachero AP, Jiménez LP, et al. Peptides and food intake. Front Endocrinol (Lausanne). 2014;5:1-13.

37. Gibbs J, Young RC, Smith GP. Cholecystokinin elicits satiety in rats with open gastric fistulas. Nature. 1973;245:323-5.

38. Antin J, Gibbs J, Holt J, et al. Cholecystokinin elicits the complete behavioral sequence of satiety in rats. J Comp Physiol Psychol. 1975;89:784-90.

39. Kissileff HR, Pi-Sunyer X, Thornton J, Smith GP. C-terminal decreases octapeptide food intake of cholecystokinin. Am J Clin Nutr 1981;154-160.
40. Lieverse RJ, Jansen JB, Masclee AM, Lamers CB. Satiety effects of cholecystokinin in humans. Gastroenterology. 1994;106:1451-4.

41. Cummings DE, Purnell JQ, Frayo RS, et al. A preprandial rise in plasma ghrelin levels suggests a role in meal initiation in humans. Diabetes. 2001;50:1714-9.

42. Cantor P, Rehfeld JF. Cholecystokinin in pig plasma: release of components devoid of a bioactive $\mathrm{COOH}$-terminus. Am $\mathrm{J}$ Physiol Gastrointest Liver Physiol. 1989;256:G53-61.

43. Luo J, Hu Y, Kong W, Yang M. Evaluation and structure-activity relationship analysis of a new series of arylnaphthalene lignans as potential anti-tumor agents. PLoS One. 2014;9:e93516.

44. Ji Z, Hadac EM, Henne RM, et al. Direct identification of a distinct site of interaction between the carboxyl-terminal residue of cholecystokinin and the type A cholecystokinin receptor using photoaffinity labeling. J Biol Chem. 1997;272:24393-401.

45. Overduin J, Gibbs J, Cummings DE, Reeve JR. CCK-58 elicits both satiety and satiation in rats while CCK- 8 elicits only satiation. Peptides. 2014;54:71-80.

46. Sayegh AI, Washington MC, Raboin SJ, et al. CCK-58 prolongs the intermeal interval, whereas CCK- 8 reduces this interval: not all forms of cholecystokinin have equal bioactivity. Peptides. 2014;55:120-5.

47. Moran TH, Robinson PH, Goldrich MS, McHugh PR. Two brain cholecystokinin receptors:implications for behavioral actions. Brain Res. 1986;362:175-9.

48. Beglinger C, Degen L, Matzinger D, et al. Loxiglumide, a CCKA receptor antagonist, stimulates calorie intake and hunger feelings in humans. Am J Physiol Regul Integr Comp Physiol. 2001;280:R1149-54.

49. Zittel TT, Glatzle J, Kreis ME, et al. C-fos protein expression in the nucleus of the solitary tract correlates with cholecystokinin dose injected and food intake in rats. Brain Res. 1999;846:1-11.

50. Moran TH, Kinzig KP. Gastrointestinal satiety signals II. Cholecystokinin. Am J Physiol Gastrointest Liver Physiol. 2004;286:G183-8.

51. Little TJ, McKie S, Jones RB, et al. Mapping glucose-mediated gut-to-brain signalling pathways in humans. Neuroimage. 2014;96:1-11.

52. Smith GP, Jerome C, Cushin BJ, et al. Abdominal vagotomy blocks the satiety effect of cholecystokinin in the rat. Science. 1981;213:1036-7.

53. Joyner K, Smith GP, Gibbs J. Abdominal vagotomy decreases the satiating potency of CCK-8 in sham and real feeding. Am J Physiol. 1993;264:R912-6.

54. Moran TH, Baldessarini AR, Salorio CF, et al. Vagal afferent and efferent contributions to the inhibition of food intake by cholecystokinin. Am J Physiol. 1997;272:R1245-51.

55. Blevins JE, Stanley BG, Reidelberger RD. Brain regions where cholecystokinin suppresses feeding in rats. Brain Res. 2000;860:1-10.

56. Edwards GL, Ladenheim EE, Ritter RC. Dorsomedial hindbrain participation in cholecystokinin-induced satiety. Am J Physiol. 1986;251:R971-7.

57. Tatemoto K, Mutt V. Isolation of two novel candidate hormones using a chemical method for finding naturally occurring polypeptides. Nature. 1980;285:417-8.

58. McGowan BMC, Bloom SR. Peptide YY and appetite control. Curr Opin Pharmacol. 2004;4:583-8.

59. Adrian TE, Ferri GL, Bacarese-Hamilton AJ, et al. Human distribution and release of a putative new gut hormone, peptide YY. Gastroenterology. 1985;89:1070-7.

60. Adrian TE, Savage AP, Sagor GR, et al. Effect of peptide YY on gastric, pancreatic, and biliary function in humans. Gastroenterology. 1985;89:494-9. 
61. Batterham RL, Heffron H, Kapoor S, et al. Critical role for peptide YY in protein-mediated satiation and body-weight regulation. Cell Metab. 2006;4:223-33.

62. Eberlein GA, Eysselein VE, Schaeffer M, et al. A new molecular form of PYY: structural characterization of human PYY(336) and PYY(1-36). Peptides. 1989;10:797-803.

63. Grandt D, Schimiczek M, Beglinger C, et al. Two molecular forms of peptide YY (PYY) are abundant in human blood: characterization of a radioimmunoassay recognizing PYY 1-36 and PYY 3-36. Regul Pept. 1994;51:151-9.

64. Grandt D, Teyssen S, Schimiczek M, et al. Novel generation of hormone receptor specificity by amino terminal processing of peptide YY. Biochem Biophys Res Commun. 1992;186:1299-306.

65. Dumont Y, Fournier A, St-Pierre S, Quirion R. Characterization of neuropeptide $\mathrm{Y}$ binding sites in rat brain membrane preparations using [125I][Leu31, Pro34]peptide YY and [125I]peptide YY3-36 as selective Y1 and Y2 radioligands. J Pharmacol Exp Ther. 1995;272:673-80.

66. Batterham RL, Cowley MA, Small CJ, et al. Gut hormone PYY(3-36) physiologically inhibits food intake. Nature. 2002;418:650-4.

67. Challis BG, Pinnock SB, Coll AP, et al. Acute effects of PYY336 on food intake and hypothalamic neuropeptide expression in the mouse. Biochem Biophys Res Commun. 2003;311:915-9.

68. Halatchev IG, Ellacott KLJ, Fan W, Cone RD. Peptide YY3-36 inhibits food intake in mice through a melanocortin-4 receptorindependent mechanism. Endocrinology. 2004;145:2585-90.

69. Sileno AP, Brandt GC, Spann BM, Quay SC. Lower mean weight after 14 days intravenous administration peptide YY3-36 (PYY3-36) in rabbits. Int J Obes (Lond). 2006;30:68-72.

70. Koegler FH, Enriori PJ, Billes SK, et al. Peptide YY(3-36) inhibits morning, but not evening, food intake and decreases body weight in rhesus macaques. Diabetes. 2005;54:3198-204.

71. Batterham RL, Cohen MA, Ellis SM, et al. Inhibition of food intake in obese subjects by peptide YY3-36. N Engl J Med. 2003;349:941-8.

72. Talsania T, Anini Y, Siu S, et al. Peripheral exendin-4 and peptide YY 3-36 synergistically reduce food intake through different mechanisms in mice. Endocrinology. 2005;146:3748-56.

73. Scott V, Kimura N, Stark JA, Luckman SM. Intravenous peptide YY3-36 and Y2 receptor antagonism in the rat: effects on feeding behaviour. J Neuroendocrinol. 2005;17:452-7.

74. Kanatani A, Mashiko S, Murai N, et al. Role of the Y1 receptor in the regulation of neuropeptide $\mathrm{Y}$-mediated feeding: comparison of wild-type, Y1 receptor-deficient, and Y5 receptor-deficient mice. Endocrinology. 2000;141:1011-6.

75. Hagan MM. Peptide YY: a key mediator of orexigenic behavior. Peptides. 2002;23:377-82.

76. Abbott CR, Monteiro M, Small CJ, et al. The inhibitory effects of peripheral administration of peptide YY 3-36 and glucagonlike peptide- 1 on food intake are attenuated by ablation of the vagal-brainstem-hypothalamic pathway. Brain Res. 2005;1044:127-31.

77. Koda S, Date Y, Murakami N, et al. The role of the vagal nerve in peripheral PYY3-36-induced feeding reduction in rats. Endocrinology. 2005;146:2369-75.

78. Brubaker PL, Anini Y. Direct and indirect mechanisms regulating secretion of glucagon-like peptide- 1 and glucagon-like peptide-2. Can J Physiol Pharmacol. 2003;81:1005-12.

79. Van Der Klaauw AA, Keogh JM, Henning E, et al. High protein intake stimulates postprandial GLP1 and PYY release. Obesity. 2013;21:1602-7.

80. Herrmann C, Göke R, Richter G, et al. Glucagon-like peptide-1 and glucose-dependent insulin-releasing polypeptide plasma levels in response to nutrients. Digestion. 1995;56:117-26.
81. Orskov C, Wettergren A, Holst JJ. Biological effects and metabolic rates of glucagonlike peptide-1 7-36 amide and glucagonlike peptide-1 7-37 in healthy subjects are indistinguishable. Diabetes. 1993;42:658-61.

82. Turton MD, O'Shea D, Gunn I, et al. A role for glucagon-like peptide- 1 in the central regulation of feeding. Nature. 1996;379:69-72.

83. Donahey JC, van Dijk G, Woods SC, Seeley RJ. Intraventricular GLP-1 reduces short- but not long-term food intake or body weight in lean and obese rats. Brain Res. 1998;779:75-83.

84. Tang-Christensen M, Vrang N, Larsen PJ. Glucagon-like peptide containing pathways in the regulation of feeding behaviour. Int J Obes Relat Metab Disord. 2001;25(Suppl 5):S42-7.

85. Meeran K, Shea DO, Edwards CMB, et al. Repeated Intracerebroventricular administration of glucagon-like peptide-1(7-36) amide or exendin-(9-39) alters body weight in the rat. Endocrinology. 1999;140:244-50.

86. Näslund E, Barkeling B, King N, et al. Energy intake and appetite are suppressed by glucagon-like peptide-1 (GLP-1) in obese men. Int J Obes Relat Metab Disord. 1999;23:304-11.

87. Gutzwiller JP, Göke B, Drewe J, et al. Glucagon-like peptide-1: a potent regulator of food intake in humans. Gut. 1999;44:81-6.

88. Zander M, Madsbad S, Madsen JL, Holst JJ. Effect of 6-week course of glucagon-like peptide 1 on glycaemic control, insulin sensitivity, and beta-cell function in type 2 diabetes: a parallelgroup study. Lancet. 2002;359:824-30.

89. Toft-Nielsen MB, Madsbad S, Holst JJ. Continuous subcutaneous infusion of glucagon-like peptide 1 lowers plasma glucose and reduces appetite in type 2 diabetic patients. Diabetes Care. 1999;22:1137-43.

90. Nauck MA, Niedereichholz U, Ettler R, et al. Glucagon-like peptide 1 inhibition of gastric emptying outweighs its insulinotropic effects in healthy humans. Am J Physiol. 1997;273:E981-8.

91. Drucker DJ. The biology of incretin hormones. Cell Metab. 2006;3:153-65.

92. Imeryüz N, Yeğen BC, Bozkurt A, et al. Glucagon-like peptide1 inhibits gastric emptying via vagal afferent-mediated central mechanisms. Am J Physiol. 1997;273:G920-7.

93. Parkinson JRC, Chaudhri OB, Kuo Y-T, et al. Differential patterns of neuronal activation in the brainstem and hypothalamus following peripheral injection of GLP-1, oxyntomodulin and lithium chloride in mice detected by manganese-enhanced magnetic resonance imaging (MEMRI). Neuroimage. 2009;44:1022-31.

94. Pocai A. Action and therapeutic potential of oxyntomodulin. Mol Metab. 2014;3:241-51.

95. Dakin CL, Gunn I, Small CJ, et al. Oxyntomodulin inhibits food intake in the rat. Endocrinology. 2001;142:4244-50.

96. Dakin CL, Small CJ, Batterham RL, et al. Peripheral oxyntomodulin reduces food intake and body weight gain in rats. Endocrinology. 2004;145:2687-95.

97. Dakin CL, Small CJ, Park AJ, et al. Repeated ICV administration of oxyntomodulin causes a greater reduction in body weight gain than in pair-fed rats. Am J Physiol Endocrinol Metab. 2002;283:E1173-7.

98. Cohen MA, Ellis SM, Le Roux CW, et al. Oxyntomodulin suppresses appetite and reduces food intake in humans. J Clin Endocrinol Metab. 2003;88:4696-701.

99. Wynne K, Park AJ, Small CJ, et al. Subcutaneous oxyntomodulin reduces body weight in overweight and obese subjects: a double-blind, randomized. Controlled Trial. Diabetes. 2005;54:2390-5.

100. Wynne K, Park AJ, Small CJ, et al. Oxyntomodulin increases energy expenditure in addition to decreasing energy intake in overweight and obese humans: a randomised controlled trial. Int J Obes (Lond). 2006;30:1729-36. 
101. Baggio LL, Huang Q, Brown TJ, Drucker DJ. Oxyntomodulin and glucagon-like peptide-1 differentially regulate murine food intake and energy expenditure. Gastroenterology. 2004; 127:546-58.

102. Kosinski JR, Hubert J, Carrington PE, et al. The glucagon receptor is involved in mediating the body weight-lowering effects of oxyntomodulin. Obesity. 2012;20:1566-71.

103. Chaudhri OB, Parkinson JRC, Kuo Y-T, et al. Differential hypothalamic neuronal activation following peripheral injection of GLP-1 and oxyntomodulin in mice detected by manganeseenhanced magnetic resonance imaging. Biochem Biophys Res Commun. 2006;350:298-306.

104. Katsuura G, Asakawa A, Inui A. Roles of pancreatic polypeptide in regulation of food intake. Peptides. 2002;23:323-9.

105. Batterham RL, Le Roux CW, Cohen MA, et al. Pancreatic polypeptide reduces appetite and food intake in humans. J Clin Endocrinol Metab. 2003;88:3989-92.

106. Hwa JJ, Witten MB, Williams P, et al. Activation of the NPY Y5 receptor regulates both feeding and energy expenditure. Am J Physiol. 1999;277:R1428-34.

107. Asakawa A, Inui A, Yuzuriha $\mathrm{H}$, et al. Characterization of the effects of pancreatic polypeptide in the regulation of energy balance. Gastroenterology. 2003;124:1325-36.

108. Michel MC, Beck-Sickinger A, Cox H, et al. XVI. International Union of Pharmacology recommendations for the nomenclature of neuropeptide $\mathrm{Y}$, peptide $\mathrm{YY}$, and pancreatic polypeptide receptors. Pharmacol Rev. 1998;50:143-150.

109. Balasubramaniam A, Mullins DE, Lin S, et al. Neuropeptide $Y$ (NPY) Y4 receptor selective agonists based on NPY(32-36): development of an anorectic Y4 receptor selective agonist with picomolar affinity. J Med Chem. 2006;49:2661-5.

110. Westermark GT, Westermark P. Islet amyloid polypeptide and diabetes. Curr Protein Pept Sci. 2013;14:330-7.

111. Cummings DE, Overduin J. Review series gastrointestinal regulation of food intake. Health Care (Don Mills). 2007;117:13-23.

112. Rushing PA, Hagan MM, Seeley RJ, et al. Amylin: a novel action in the brain to reduce body weight. Endocrinology. 2000;141:850-3.

113. Lutz TA, Geary N, Szabady MM, et al. Amylin decreases meal size in rats. Physiol Behav. 1995;58:1197-202.

114. Chapman I, Parker B, Doran S, et al. Effect of pramlintide on satiety and food intake in obese subjects and subjects with type 2 diabetes. Diabetologia. 2005;48:838-48.

115. Lutz TA, Althaus J, Rossi R, Scharrer E. Anorectic effect of amylin is not transmitted by capsaicin-sensitive nerve fibers. Am J Physiol. 1998;274:R1777-82.

116. Lutz TA. Pancreatic amylin as a centrally acting satiating hormone. Curr Drug Targets. 2005;6:181-9.

117. Burke LE, Wang J. Treatment strategies for overweight and obesity. J Nurs Scholarsh. 2011;43:368-75.

118. Kushner RF. Weight loss strategies for treatment of obesity. Prog Cardiovasc Dis. 2014;56:465-72.

119. Samaranayake NR, Ong KL, Leung RYH, Cheung BMY. Management of Obesity in the National Health and Nutrition Examination Survey (NHANES), 2007-2008. Ann Epidemiol. 2012;22:349-53.

120. Kakkar AK, Dahiya N. Drug treatment of obesity: current status and future prospects. Eur J Intern Med. 2015;26:89-94.

121. Karra E, Yousseif A, Batterham RL. Mechanisms facilitating weight loss and resolution of type 2 diabetes following bariatric surgery. Trends Endocrinol Metab. 2010;21:337-44.

122. Tack J, Deloose E. Complications of bariatric surgery: dumping syndrome, reflux and vitamin deficiencies. Best Pract Res Clin Gastroenterol. 2014;28:741-9.
123. Akkary E. Bariatric surgery evolution from the malabsorptive to the hormonal era. Obes Surg. 2012;22:827-31.

124. Michalakis K, Le Roux C. Gut hormones and leptin: impact on energy control and changes after bariatric surgerywhat the future holds. Obes Surg. 2012;22:1648-57.

125. Tsoli M, Chronaiou A, Kehagias I, et al. Hormone changes and diabetes resolution after biliopancreatic diversion and laparoscopic sleeve gastrectomy: a comparative prospective study. Surg Obes Relat Dis. 2013;9:667-77.

126. Dimitriadis E, Daskalakis M, Kampa M, et al. Alterations in gut hormones after laparoscopic sleeve gastrectomy: a prospective clinical and laboratory investigational study. Ann Surg. 2013;257:647-54.

127. Yousseif A, Emmanuel J, Karra E, et al. Differential effects of laparoscopic sleeve gastrectomy and laparoscopic gastric bypass on appetite, circulating acyl-ghrelin, peptide YY3-36 and active GLP-1 levels in non-diabetic humans. Obes Surg. 2014;24:241-52.

128. Sweeney TE, Morton JM. Metabolic surgery: action via hormonal milieu changes, changes in bile acids or gut microbiota? A summary of the literature. Bailliere's Best Pract Res Clin Gastroenterol. 2014;28:727-40.

129. Stoeckli R, Chanda R, Langer I, Keller U. Changes of body weight and plasma ghrelin levels after gastric banding and gastric bypass. Obes Res. 2004;12:346-50.

130. Dixon AFR, Dixon JB, O'Brien PE. Laparoscopic adjustable gastric banding induces prolonged satiety: a randomized blind crossover study. J Clin Endocrinol Metab. 2005;90:813-9.

131. Rodieux F, Giusti V, D'Alessio DA, et al. Effects of gastric bypass and gastric banding on glucose kinetics and gut hormone release. Obesity (Silver Spring). 2008;16:298-305.

132. Korner J, Inabnet W, Febres G, et al. Prospective study of gut hormone and metabolic changes after adjustable gastric banding and Roux-en-Y gastric bypass. Int J Obes. 2009;33:786-95.

133. Krieger AC, Youn H, Modersitzki F, et al. Effects of laparoscopic adjustable gastric banding on sleep and metabolism: a 12-month follow-up study. Int J Gen Med. 2012;5:975-81.

134. Borg CM, Le Roux CW, Ghatei MA, et al. Progressive rise in gut hormone levels after Roux-en-Y gastric bypass suggests gut adaptation and explains altered satiety. $\mathrm{Br} \quad \mathrm{J}$ Surg. 2006;93:210-5.

135. Le Roux CW, Aylwin SJB, Batterham RL, et al. Gut hormone profiles following bariatric surgery favor an anorectic state, facilitate weight loss, and improve metabolic parameters. Ann Surg. 2006;243:108-14.

136. Pournaras DJ, Osborne A, Hawkins SC, et al. The gut hormone response following roux-en-Y gastric bypass: cross-sectional and prospective study. Obes Surg. 2010;20:56-60.

137. Ockander L, Hedenbro JL, Rehfeld JF, Sjölund K. Jejunoileal bypass changes the duodenal cholecystokinin and somatostatin cell density. Obes Surg. 2003;13:584-90.

138. Buchan AM, Pederson RA, Koop I, et al. Morphological and functional alterations to a sub-group of regulatory peptides in human pancreas and intestine after jejuno-ileal bypass. Int $\mathrm{J}$ Obes Relat Metab Disord. 1993;17:109-13.

139. Näslund E, Grybäck P, Hellström PM, et al. Gastrointestinal hormones and gastric emptying 20 years after jejunoileal bypass for massive obesity. Int $\mathrm{J}$ Obes Relat Metab Disord. 1997;21:387-92.

140. Neary NM, Small CJ, Druce MR, et al. Peptide YY3-36 and glucagon-like peptide-17-36 inhibit food intake additively. Endocrinology. 2005;146:5120-7. doi:10.1210/en.2005-0237.

141. Buse JB, Henry RR, Han J, et al. Effects of exenatide (exendin4) on glycemic control over 30 weeks in sulfonylurea-treated patients with type 2 diabetes. Diabetes Care. 2004;27:2628-35. 
142. DeFronzo RA, Ratner RE, Han J, et al. Effects of exenatide(Exendin-4) on glycemic control and weight over 30 Weeks in metformin-treated patients with Type 2 diabetes. Diabetes Care. 2005;28:1092-100.

143. Kendall DM, Riddle MC, Rosenstock J, et al. Effects of exenatide (exendin-4) on glycemic control over 30 weeks in patients with type 2 diabetes treated with metformin and a sulfonylurea. Diabetes Care. 2005;28:1083-91.

144. Steinert R, Poller B, Castelli M. Orally administered glucagonlike peptide-1 affects glucose homeostasis following an oral glucose tolerance test in healthy male subjects. Clin Pharmacol. 2009;86:644-50.

145. Jang H-J, Kokrashvili Z, Theodorakis MJ, et al. Gut-expressed gustducin and taste receptors regulate secretion of glucagon-like peptide-1. Proc Natl Acad Sci USA. 2007;104:15069-74.

146. Steinert RE, Gerspach AC, Gutmann H, et al. The functional involvement of gut-expressed sweet taste receptors in glucosestimulated secretion of glucagon-like peptide-1 (GLP-1) and peptide YY (PYY). Clin Nutr. 2011;30:524-32. 